\title{
Oriented morphogenetic phenomena in cambium of broadleaved tress
}

\section{Z. HEJNOWICZ AND J. KRAWCZYSZYN}

In the cambium of conifers oblique anticlinal divisions tend to be oriented so that the resulting anticlinal partitions are inclined in a like direction in neighbouring cells (B a n n a n 1950, 1964, 1966; Hejnowic z 1961, 1964; J on es 1963; S mith 1967). The same unidirectional tendencies are manifested also in the orientation of overlap achieved by intrusively growing cell tips (B a $\mathrm{n}$ an 1966; Hejnowicz 1968). A unidirectional tendency holds throughout a cambial area of as yet undermined shape and size until, after a time, the orientation becomes reversed. Such a tendency, extended in space and time, is the basis for the changing inclination of cambial initials with respect to the stem axis and may have an importan't bearing on the grain of the wood (Bannan 1966; Hejnow ic z 1968).

Oblique anticlinal divisions and intrusive growth also occur in cambium of dicotyledons (Evert 1961; C h e a d l e and E s a u 1964; C u mbi e 1967), but we do not know if they are as subject to unidirectional tendencies as in conifer cambium. C u mbie (1967) reported that in the shrub Leitneria both directions of tilt in pseudotransverse divisions are equally frequent, but perhaps this is more a characteristic of Leitneria than of woody dicotyledons in general.

The scantiness of the information is probably due to difficulties in tracing of developmental changes in cambia of broadleaved trees. The cambial cell pattern, in general, is not preserved in the xylem of these trees, so the relatively simple method of tracing the changes by using serial tangential sections of the xylem, developed for conifers, cannot be used.

A comparison of the basic cell pattern in the terminal layer of late xylem (TLX) of the outer annual ring with that in the adjacent cambium in dormant trees led us to conclude that the cambium leaves a legible record of its cellular state in TLX (Fig. 1). Thus this record provides an opportunity to one to follow the developmental changes in cambium of broadleaved trees by using the TLX layers from successive annual rings. 


\section{MATERIALS AND METHODS}

The samples of xylem used in this study are described in Table 1. Serial tangential sections $30 \mu$ thick were cut from the samples. Special efforts were made to cut the xylem in the plane of the border between annual rings. Sections from the midlle part of the ring were discarded. Remaining sections were arranged on slides in serial order and attached with Haupt's adhesive. They were then dried, immersed in boiling alcohol to remove the air from cell lumina, passed through xylene, and mounted in Canada balsam. Images of the sections containing TLX were projected onto photographic paper by using a Zeiss Documator. The enlargement was mostly 80 fold. Often one photograph of a TLX layer was a composite of several parts if different sectors of the layer were present in different sections (usually the layer was not thicker than 1 section, but only a part of the layer was in the plane of sectioning). The photographs of the successive layers provided the direct object of the studies. If necessary the studies were completed by inspecting the sections themselves under a microscope.

\section{RESULTS}

Fig. 1 provides the proof that the TLX layer replicates the basic cell pattern which occured in the cambium during the formation of this layer. It may be seen that the cell pattern in the TLX and in the adjacent dormant cambium are nearly identical except for the transverse partitions in the former which were formed during the differentiation of xylem parenchyma.

What can be deduced by studying the cell pattern in successive TLX layers? Are they sufficient for drawing inferences about the orientation of anticlinal divisions in cambial initials and the direction of intrusive growth of the initials? The answer is summarized in Table 2. In general, the orientation of anticlinal divisions can be determined by using the TLX layers if the developmental changes during formation of the annual ring separating two TLX layers were not too intensive. This condition usually is fulfilled by xylem with narrow annual rings located far from the pith. Thus we were able to determine the orientation in sample no. 1 of Alnus, but not in sample no. 2. We were not able to identify the newly formed anticlinal partitions in the Liriodendron sample characterized by wide rings. Sometimes technical difficulties in obtaining appropriate sections with TLX made impossible the tracing of developmental changes in the cambium, as, for instance, in Carpinus.

Among the materials listed in Table 1 we were able to trace anticlinal 
Table 1

Samples of xylem studied

\begin{tabular}{|c|c|c|c|c|c|}
\hline \multirow[b]{2}{*}{ Species, no. } & \multirow[b]{2}{*}{ Locality } & \multirow[b]{2}{*}{$\begin{array}{l}\text { Sample } \\
\text { shape }\end{array}$} & \multicolumn{2}{|c|}{ Sample position } & \multirow[b]{2}{*}{$\begin{array}{l}\text { Aring no. } \\
\text { outward } \\
\text { from pith }\end{array}$} \\
\hline & & & $\begin{array}{l}\text { height } \\
\text { m. }\end{array}$ & $\begin{array}{l}\text { distance } \\
\text { from pith } \\
\text { mm. }\end{array}$ & \\
\hline Alnus glutinosa no. 1 & Sudeten & radial strip & unknown & $105-135$ & $42-63$ \\
\hline$,, \quad, \quad$ no. 2 & Zmigrod & & 1.5 & $40-70$ & $5-7$ \\
\hline $\begin{array}{c}\text { Aesculus hippocastanum } \\
\text { no. } 1\end{array}$ & Chwalimierz & ,, ," & 1.5 & $45-230$ & $18-80$ \\
\hline , & & $\begin{array}{l}\text { tangential } \\
\text { rectangle } \\
2.1 \times 4.5 \mathrm{~cm}\end{array}$ & ", & $85-92$ & $26-28$ \\
\hline , $\quad$ no. 2 & Zmigrod & radial strip & $\begin{array}{l}1.0 \\
10\end{array}$ & $\begin{array}{c}6-47 \\
\text { about } 200\end{array}$ & $\begin{array}{c}2-9 \\
5 \text { outer }\end{array}$ \\
\hline $\begin{array}{r}, \quad \text { no. } 3 \\
\text { Liriodendron tulipifera }\end{array}$ & $\begin{array}{l}\text { Wrocław } \\
\text { North } \\
\text { America }\end{array}$ & $\begin{array}{l}\stackrel{\prime \prime}{\prime \prime} \\
\text { tangential } \\
\text { rectangle } \\
12 \times 4.5 \mathrm{~cm}\end{array}$ & $\begin{array}{c}1.0 \\
\text { unknown }\end{array}$ & $\begin{array}{c}\text { about } 200 \\
103-117\end{array}$ & $\begin{array}{l}5 \text { outer r. } \\
23-26\end{array}$ \\
\hline Acer pseudoplatanus & Chwalimierz & radial strip & 2.0 & $50-60$ & $17-21$ \\
\hline Betula verrucosa & , & , & 4.0 & $80-95$ & $18-22$ \\
\hline Carpinus betulus & , & , & 2.0 & $60-65$ & $\begin{array}{ll}44-48 \\
-1\end{array}$ \\
\hline Populus tremula & , & , & 2.0 & $15-50$ & $3-10$ \\
\hline Fraxinus excelsior &, &,,$\quad$, & 12.0 & 140 & $56-60$ \\
\hline
\end{tabular}

Table 2

Summary of the possibilities offered by TLX layers for determining the history of changes in cambium

\begin{tabular}{|c|c|c|}
\hline $\begin{array}{l}\text { Species } \\
\text { and sample of } \\
\text { xylem }\end{array}$ & $\begin{array}{l}\text { Identification of the deriva- } \\
\text { tives of a fusiform initials } \\
\text { in two succesive TLX } \\
\text { layers }\end{array}$ & What can be deduced \\
\hline $\begin{array}{l}\text { Liriodendron tulipifera } \\
\text { Acer pseudoplatanus } \\
\text { Betula verrucosa } \\
\text { Carpinus betulus } \\
\text { Populus tremula } \\
\text { Fraxinus excelsior }\end{array}$ & $\begin{array}{l}\text { not possible in most sites } \\
\text { where changes took place } \\
\text { easy } \\
\text { rather difficult } \\
\text { difficult } \\
\text { very difficult } \\
\text { easy }\end{array}$ & $\begin{array}{l}\text { orientation of anticlinal partitions, } \\
\text { loss of initials, intrusive elongation } \\
\text { nothing } \\
\text { orientation of anticlinal partitions, } \\
\text { loss of inititials, splitting of rays, } \\
=\text { intrusive elongation } \\
\text { direction in which multiseriate rays } \\
\text { are splitted = orientation of intru- } \\
\text { sive growth } \\
\text { as in Aesculus } \\
\text { orientation of anticlinal partitions } \\
\text { splitting of rays } \\
\text { nothing } \\
\text { no changes were observed in the } \\
\text { sample studied }\end{array}$ \\
\hline
\end{tabular}


divisions in Alnus (older stem), Aesculus, Acer, and Betula. Nearly all newly formed anticlinal partitions were perpetuated in the next TLX layers which means that corresponding anticlinal divisions took place in cambial initials. The partitions were always oblique with an average length about one quarter of that of the mother cell (Table 3 column 4). Was the obliquity directly due to obliquity of anticlinal division or was it a secondary consequence of intrusive growth occuring after transverse division? The orientation of anticlinal partitions observed in the TLX layer may reflect not only the orientation of pseudotransverse cell plates at the completion of cytokinesis in dividing fusiform initials, but other subsequent events as well. The latter would include any intrusive elongation of the daughter initials themselves and of the developing derivatives of these initials. However, in preliminary studies on tangential sections of the cambium collected in different phases of its activity from the mentioned species we observed newly formed anticlinal walls with inclinations and lengths similar to these in TLX. On this basis we assume that the oblique anticlinal partitions in TLX correspond to pseudotransverse anticlinal divisions in the cambium, and that the orientation of the former indicates the orientation of the latter.

In Alnus the orientation was evidently not random (Table 3, column 5 and 6). The dominant orientation within the small area studied was initially to the left (S) then it reversed and for many years was to the right $(\mathrm{Z})$. The conformity in the orientation was very high, especially when the prevailing direction was to the right.

In Aesculus the tendency for predominance of one direction was observed in many rings; however, in some there was no preference of orientation. The prevailing direction was more often $\mathrm{S}$ than $\mathrm{Z}$. It should be mentioned that more than 60 rings from sample no. 1 were studied, but only those rings in which at least 10 anticlinal partitions were determined within the studied area are listed in Table 3. A general predominance of S-partitions in Aesculus is interesting in view of the general occurence of spiral grain tilted in the Z-direction. The sample trees were typical in this respect. The discrepancy between inclination of the divisions and of spiral grain was the reason we studied more than one specimen of the species.

In Acer and Betula the number of oblique partitions inclined in one direction was about equal to the number inclined in the opposite direction within the small area studied. Obviously this does not mean that the orientation is random in this species; more extensive studies are needed.

In conifers, the cambium shows a pattern of areas (domains) which differ in the direction of inclination of pseudotransverse walls. Similar 
Table 3

Frequency of anticlinal divisions, mean relative length and the orientation of anticlinal partitions.

The area studied was about $20 \mathrm{~mm}^{2}$

\begin{tabular}{|c|c|c|c|c|c|c|}
\hline \multirow{2}{*}{$\begin{array}{c}\text { Ring outward } \\
\text { from pith no. } \\
1\end{array}$} & \multirow{2}{*}{$\begin{array}{l}\text { Ring width } \\
\text { mm. } \\
2\end{array}$} & \multirow{2}{*}{$\begin{array}{l}\text { Frequency } \\
\text { of ant. d. } \\
\text { no. } / \mathrm{mm} . \\
3\end{array}$} & \multirow{2}{*}{$\begin{array}{c}\text { Length relati- } \\
\text { ve to mother } \\
\text { cell } \% \\
4\end{array}$} & \multicolumn{2}{|c|}{$\begin{array}{l}\text { Percentage } \\
\text { of partitions }\end{array}$} & \multirow{2}{*}{$\begin{array}{c}\text { Dominant } \\
\text { orientation } \\
6\end{array}$} \\
\hline & & & & & & \\
\hline \multicolumn{7}{|c|}{ Alnus glutinosa no. 1} \\
\hline 42 & 1.8 & 0.023 & 26 & 75 & 25 & $\mathrm{Z}$ \\
\hline 43 & 1.3 & 0.021 & 30 & 79 & 21 & $\mathrm{Z}$ \\
\hline 44 & 2.4 & 0.009 & 23 & 63 & 37 & $\mathrm{Z}$ \\
\hline 45 & 2.0 & 0.011 & 33 & 81 & 19 & $\mathrm{Z}$ \\
\hline 46 & 1.8 & 0.028 & 29 & 100 & 0 & $\mathrm{Z}$ \\
\hline 47 & 2.0 & 0.019 & 29 & 18 & 82 & $\mathrm{~S}$ \\
\hline 48 & 1.8 & 0.021 & 30 & 4 & 96 & $\mathrm{~S}$ \\
\hline 49 & 1.6 & 0.030 & 30 & 5 & 95 & $\mathrm{~S}$ \\
\hline 50 & 1.3 & 0.024 & 28 & 4 & 96 & $\mathrm{~S}$ \\
\hline 51 & 1.4 & 0.010 & 27 & 0 & 100 & $\mathrm{~S}$ \\
\hline 52 & 1.4 & 0.013 & 28 & 0 & 100 & $\mathrm{~S}$ \\
\hline $53-54$ & 1.5 & 0.013 & 24 & 0 & 100 & $\mathrm{~S}$ \\
\hline $55-56$ & 2.1 & 0.022 & 30 & 6 & 94 & $\mathrm{~S}$ \\
\hline $57-60$ & 2.6 & 0.042 & 24 & 0 & 100 & $\mathrm{~S}$ \\
\hline $61--63$ & 2.3 & 0.060 & 26 & 0 & 100 & $\mathrm{~S}$ \\
\hline \multicolumn{7}{|c|}{ Aesculus hippocastanum no. 2} \\
\hline 2 & 3.2 & 0.187 & 36 & 83 & 17 & $\mathrm{Z}$ \\
\hline 3 & 4.1 & 0.134 & 29 & 91 & 9 & $\mathrm{Z}$ \\
\hline 4 & 4.4 & 0.114 & 55 & 70 & 30 & $\mathrm{Z}$ \\
\hline 6 & 6.8 & 0.029 & 31 & 50 & 50 & - \\
\hline 7 & 11.3 & 0.049 & 28 & 36 & 64 & (S) \\
\hline 8 & 5.0 & 0.093 & 30 & 27 & 73 & $\mathrm{~S}$ \\
\hline 9 & 5.0 & 0.200 & 29 & 90 & 10 & $\mathrm{Z}$ \\
\hline \multicolumn{7}{|c|}{ Aesculus hippocastanum no. 1} \\
\hline 20 & 6.7 & 0.028 & 27 & 30 & 70 & $\mathrm{~S}$ \\
\hline 22 & 5.0 & 0.023 & 26 & 40 & 60 & - \\
\hline 23 & 6.5 & 0.011 & 33 & 11 & 89 & $\mathrm{~S}$ \\
\hline 24 & 5.0 & 0.025 & 30 & 0 & 100 & $\mathrm{~S}$ \\
\hline 65 & 4.5 & 0.007 & 28 & 0 & 100 & $\mathrm{~S}$ \\
\hline 85 & 2.4 & 0.015 & 33 & 0 & 100 & $\mathrm{~S}$ \\
\hline \multicolumn{7}{|c|}{ Aesculus hippocastanum no. 3} \\
\hline 1963 (year) & 2.0 & 0.200 & 30 & 0 & 100 & $\mathrm{~S}$ \\
\hline 1964 & 2.1 & 0.111 & 31 & 33 & 67 & (S) \\
\hline 1965 & 4.5 & 0.122 & 26 & 64 & 36 & (Z) \\
\hline 1966 & 3.0 & 0.200 & 32 & 89 & 11 & $\mathrm{Z}$ \\
\hline 1967 & 4.1 & 0.116 & 40 & 55 & 45 & - \\
\hline \multicolumn{7}{|l|}{ Acer pseudoplatanus } \\
\hline 18 & 2.5 & 0.068 & 25 & 61 & 39 & (Z) \\
\hline 19 & 2.0 & - & 23 & 42 & 58 & - \\
\hline 20 & 1.8 & - & 24 & 58 & 42 & - \\
\hline \multicolumn{7}{|l|}{ Betula verrucosa } \\
\hline 19 & 3.0 & 0.050 & 37 & 71 & 29 & $\mathrm{Z}$ \\
\hline 20 & 5.5 & 0.042 & 31 & 53 & 47 & - \\
\hline 21 & 4.0 & 0.016 & 22 & 50 & 50 & - \\
\hline 22 & 5.0 & 0.044 & 31 & 47 & 53 & - \\
\hline
\end{tabular}




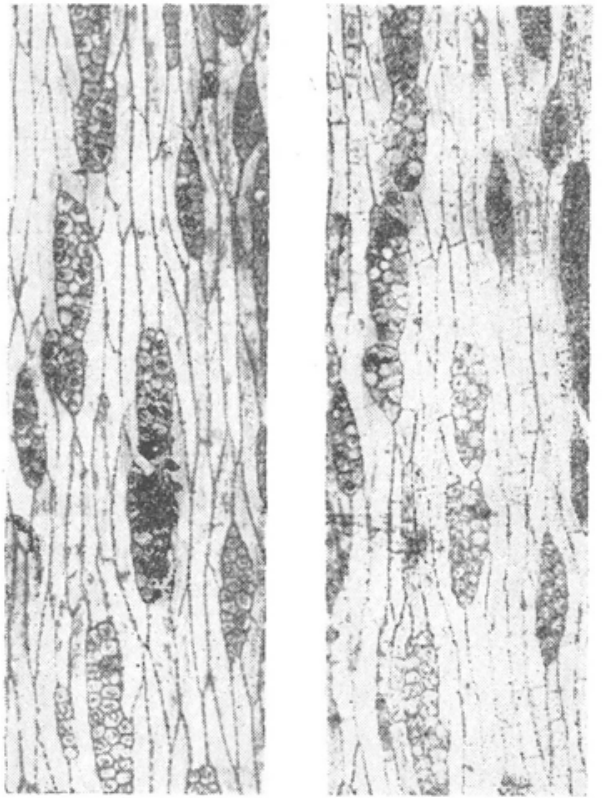

\section{FRAXINUS}

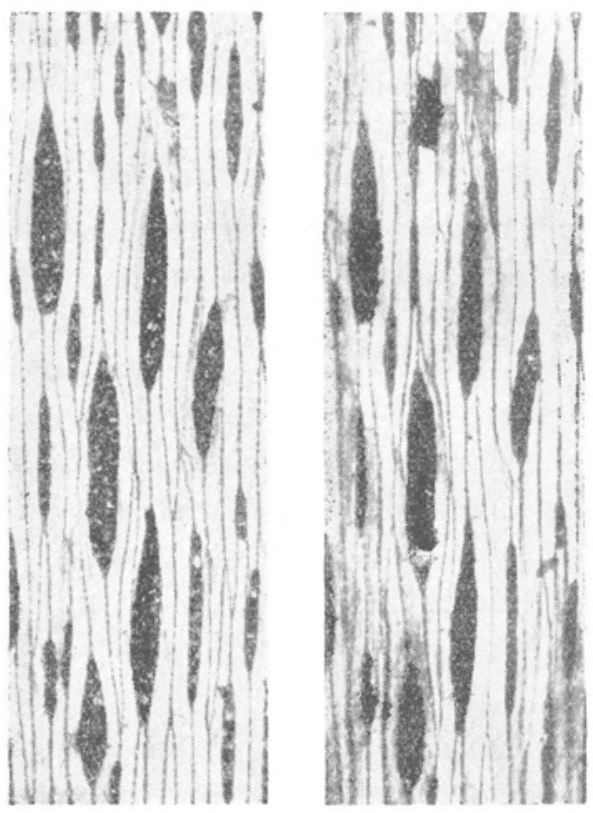

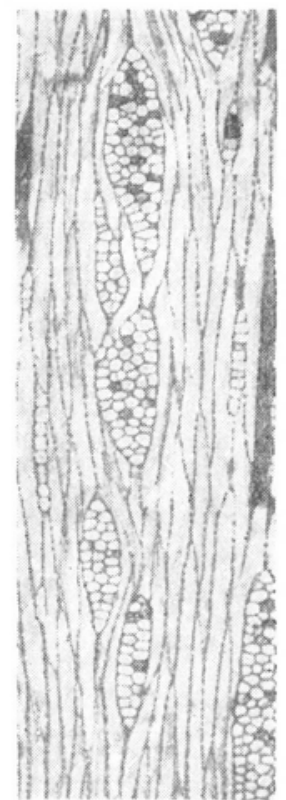

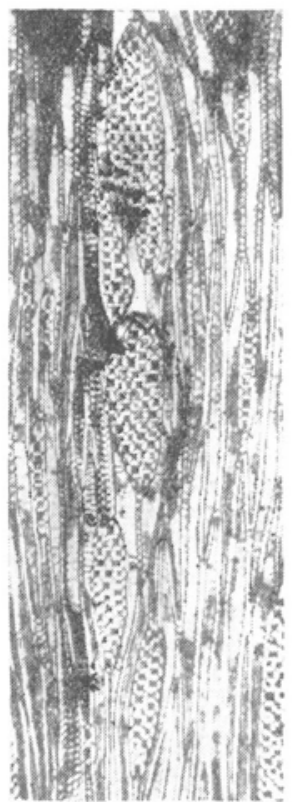

\section{ACER}

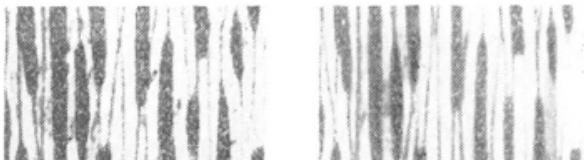
13 1) 18 : . 1 (1)

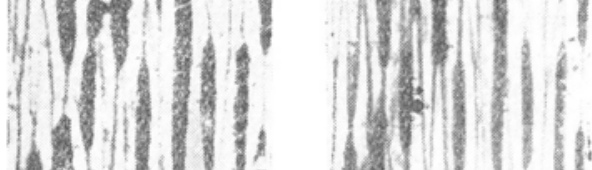
(4) 1)

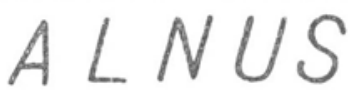

Fig. 1 Cell patterns in terminal xylem layer of outer annual rings (the left photograph of each pair) and in the corresponding area of adjacent cambium from dor- 

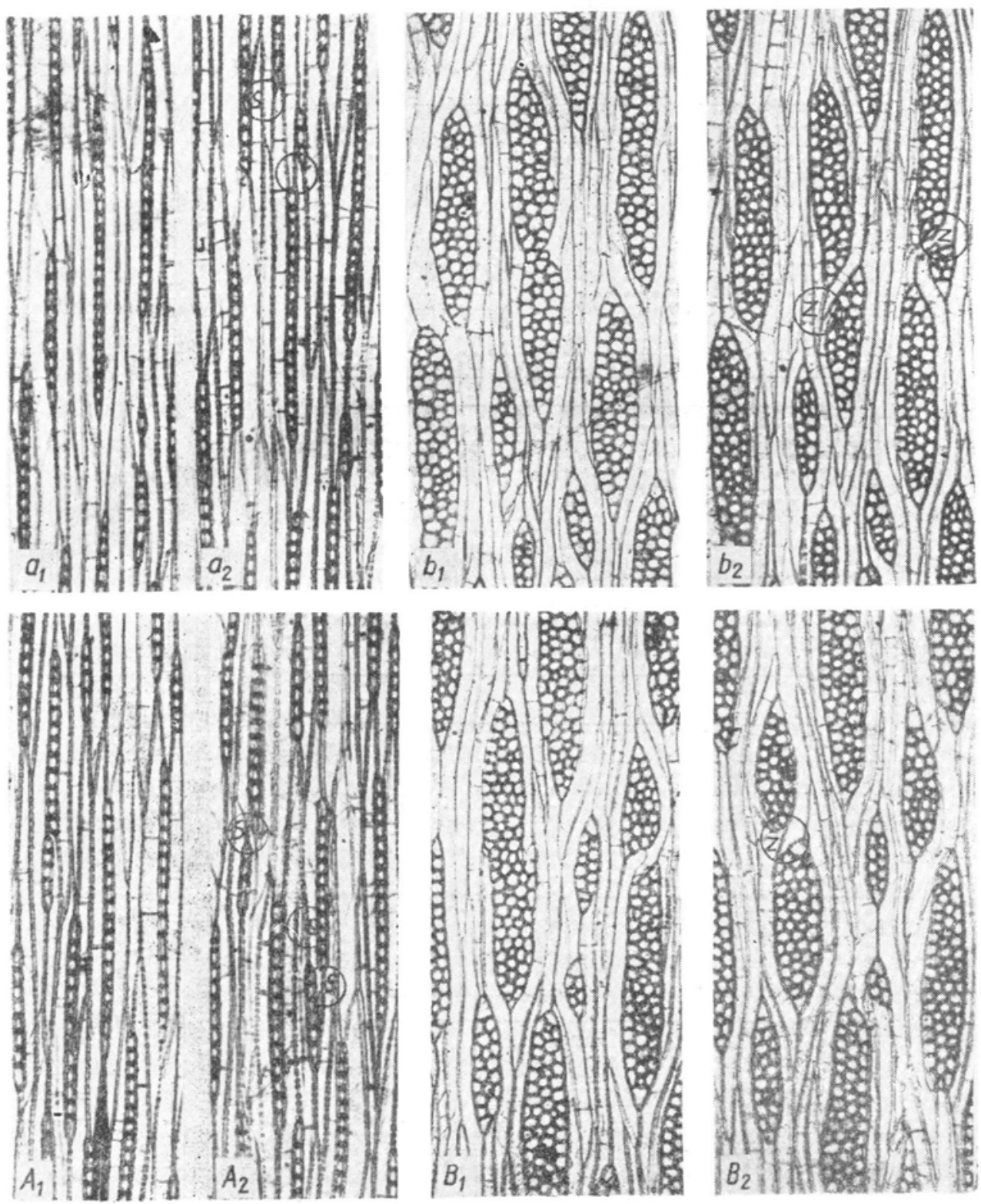

Fig. 2. Splitting of rays in Aesculus (A and a) and in Liriodendron (B and b). The same tangential area in two successive terminal xylem layers, 1 - before splitting, 2 - after splitting. Circles on rays in 2 show the sites of ray splitting. One circle on each of $\mathrm{A}_{2}$ and a2 also shows a newly formed partition. 

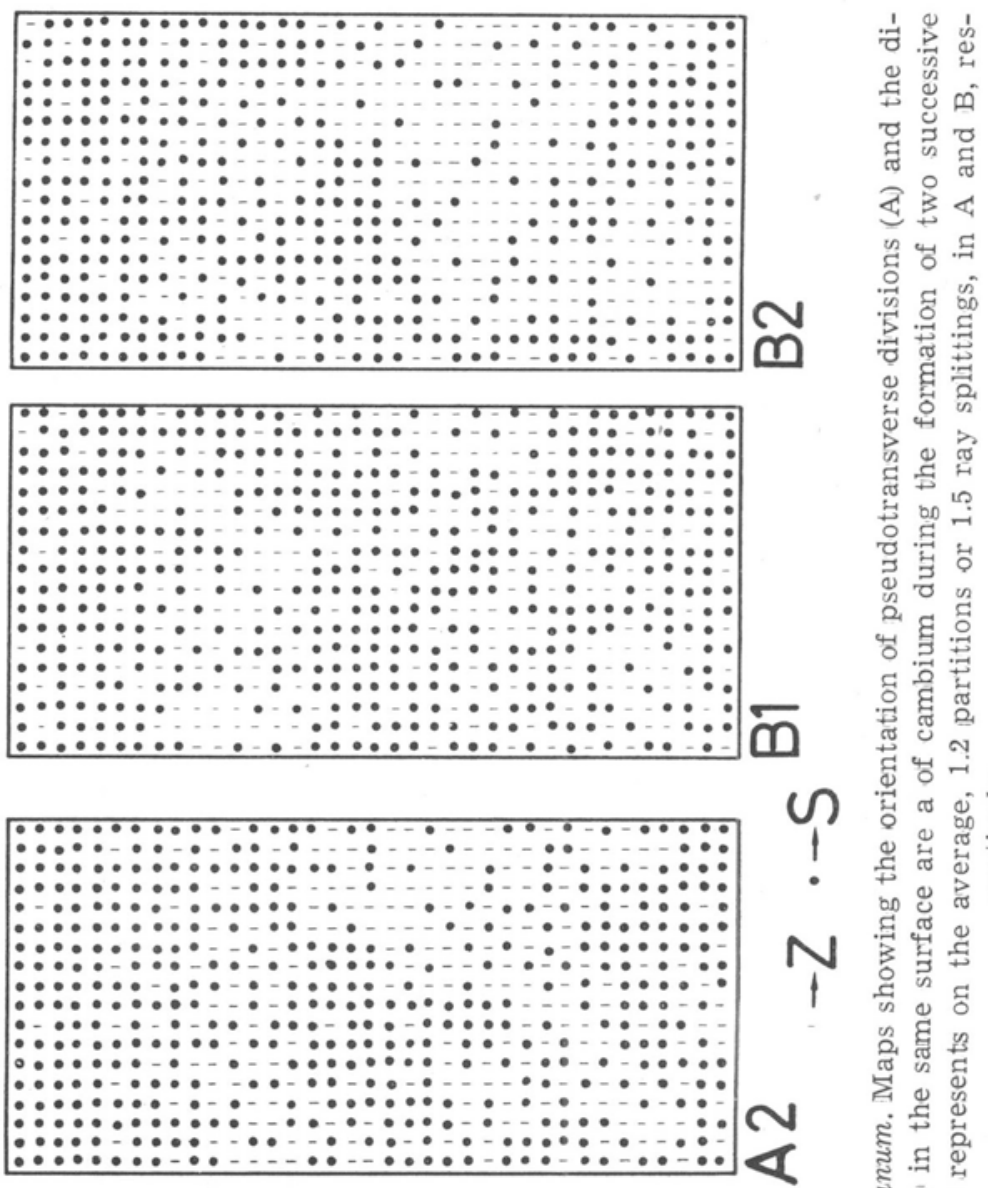

0

$\bullet \bullet \bullet \bullet \bullet \bullet \bullet \bullet \bullet-\bullet-\bullet \bullet-\ldots \bullet-\ldots, \bullet-\bullet \ldots-\bullet \bullet \bullet \bullet \bullet \bullet \bullet \bullet \bullet$

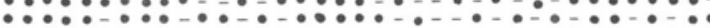

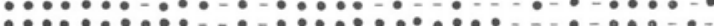
$\bullet-\bullet \bullet \bullet-\bullet$

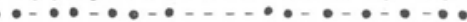
$\bullet \bullet \bullet \bullet \bullet \bullet \bullet \bullet \bullet-\ldots \bullet \bullet-\bullet-\bullet \bullet \bullet \bullet-\bullet \ldots \bullet \bullet \bullet-\ldots . . \bullet$ :

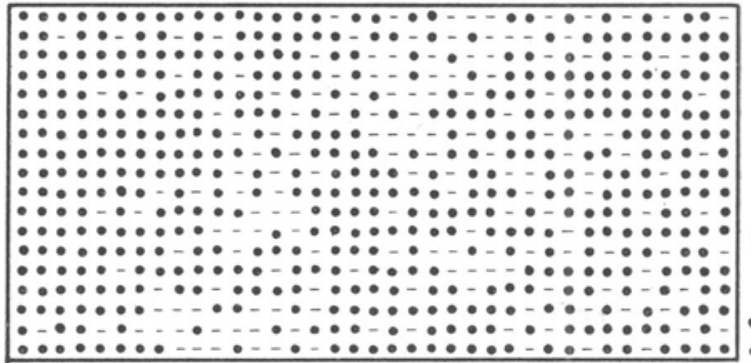

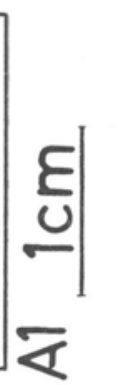

. 
domain patterns may also be expected in the cambium of broadleaved trees. We attempted to study this pattern in Aesculus. For this purpose we divided a sample of xylem, with tangential dimensions of $21 \times 45 \mathrm{~mm}$ (Table 1) into 15 blocks appriopriate for sectioning, photographed the cell pattern in 3 successive TLX layers over the whole tangential surface of each block and determined as many of the newly formed anticlinal partitions as possible. The surface corresponding to one block (about $50 \times 70$ $\mathrm{mm}$ on the photograph) was divided into quarters and the ratio of $\mathrm{Z}$ - to S-partitions was calculated for each quarter (total number of the partitions in a quarter averaged 16). The quarters were outlined, in the proper place and scale within the rectangle representing the whole area studied. This was done on a sheet of paper with uniformly distributed points. The points within the area corresponding to a quarter were covered by dashes and circles so that the ratio of dashes to circles was the same as that of $\mathrm{Z}$ to $\mathrm{S}$ divisions. In this way the cambium was mapped with respect to the orientation of pseudotransverse divisions which occured during the production of an annual ring. The maps of the same area in two successive rings are shown in Fig. $3\left(\mathrm{~A}_{1}\right.$ and $\left.\mathrm{A}_{2}\right)$. The upper portion and the right. lower corner of the studied area showed a high predominance of $\mathrm{S}$ partitions in both rings. In the remaining portion some parts were indeterminate in orientation and some, showed a predominance of $\mathrm{Z}$ partitions $\left(\mathrm{A}_{2}\right)$. Comparison of the maps indicates that the pattern did not change significantly during the production of the two rings except that the $\mathrm{Z}$ pattern was more pronounced in the second ring.

We also looked for an indication of oriented tendencies in direction of intrusive growth. It was difficult to gather data about the direction in which tips of two fusiform initials overlapped. However, we have found a possibility of another approach to the problem. A ray which was a single unit on one TLX layer often was bissected in the next layer in Aesculus, Liriodendron and Carpinus (Fig. 2). This dissection was of the Z- or S-type. Two interpretations of the dissection are possible. Either the tip of a neighboring fusiform initial penetrated the ray, or a ray initial elongated and assumed the character of fusiform initial (B a r g h o or n 1941; Cheadle and Es a u 1964). The cell pattern in TLX of the mentioned species indicates the former possibility. Thus we might determine the direction of intrusive growth by noting the direction in which rays are split.

In Aesculus we studied the direction of intrusive growth simultaneously with the orientation of pseudotransverse divisions. The intrusive growth direction was mapped in a way similar to that described for divisional orientation (Fig. $3 \mathrm{~B}_{1}$ and $\mathrm{B}_{2}$ ). It can be seen that in some areas the direction of intrusive growth was not random; one direction strongly prevailed. Comparison of the maps B and A indicates a general conformity 

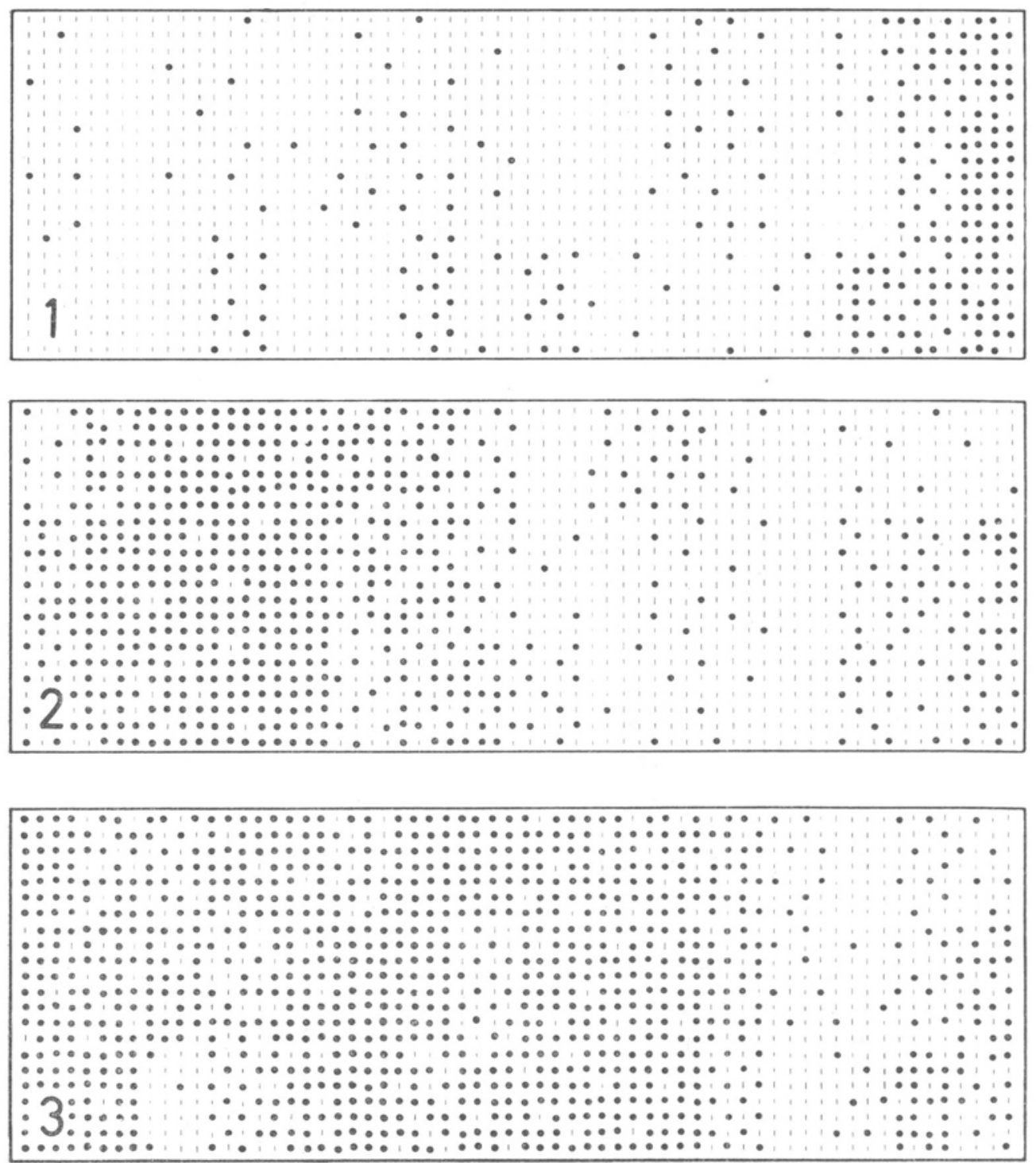

\section{$5 \mathrm{~cm}$}

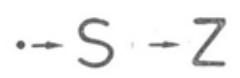

Fig. 4. Liriodendron tulipifera. Maps showing direction of ray splitting on the same surface area of cambium during the formation of 3 suocessive annual rings. 
between the direction of intrusive growth and the orientation of pseudotransverse divisions, that is, the domain pattern in $\mathrm{B}$ replicates the pattern in A.

In Liriodendron about $2 \%$ of the multiseriate rays were split during the production of one ring. The direction of splitting, i.e. the direction of intrusive growth was definitely not random. This is evident in Fig. 4. Comparison of the same area of cambium in three successive years indicated that the domain pattern changed with time. The developmental changes in this species undoubtedly involved oblique anticlinal divisions ( $\mathrm{Ch}$ e a d le and Es a u 1964), however in our material we did not succeeded in separating the anticlinal divisions from other changes, such as intrusive elongation and loss of initials by using the TLX layers. Consequently the orientation of the anticlinal divisions was not determined. We may nevertheless expect that it was not random on the basis of our observations on ray splitting in this species and on the observation made on Aesculus that the orientation of pseudotransverse divisions and the direction of intrusive growth are correlated.

In Carpinus the surface of annual rings was full of narrow longitudinal grooves which made impossible the preparation of tangential sections with appriopriately cut TLX layers. For this reason we were not able to determine the orientation of newly formed anticlinal partitions. It was possible however to determine the direction of splitting of rays. The latter was not random in a sector which increased tangentially and in all 5 successive rings studied the S-direction prevailed $(75 \%)$.

\section{DISCUSSION}

The TLX layer can preserve the cambial cell pattern because of the suppression of intrusive growth during the differentiation of the layer. This suppression is probably due to some enviromental factors which characterize the end of the growing season. Perhaps short photoperiods are important in this respect. The figures in the paper of W e is e l and $\mathrm{F}$ a h n (1965) indicate that short photoperiods inhibited intrusive growth during xylem differentation in Robinia; transverse sections of xylem formed by Robinia under short day conditions show radial arrangement of cells undistorted by intrusive growth, in contrast to xylem formed under long day conditions. It thus seems possible to find a factor, or factors, which will induce the formation of a wood layer preserving the cambial cell pattern during the main growth season also and to shorten the period during which the cambium does not leave a legible record of its cellular state in the xylem. We suggest that studies of the develop- 
mental changes in cambium based on successive TLX layers, or any other layers of xylem with preserved cambial cell patterns are easier than studies based on serial tangential sections of secondary phloem (E ver t 1961; C h e a d l e and E s a u 1964).

Pseudotransverse divisions and intrusive growth of cambial initials represent processes which may proceed either to the left or to the right. The data presented in this paper indicate that the choice of direction is not random in the cambium of broadleaved trees. There is a tendency toward predominance of one direction in any particular locality of the cambium. The data indicate a pattern of localities characterized by directional conformity in the cambium (Aesculus, Liriodendron). The pattern may change with time (Liriodendron). Within a particular locality of the cambium there also tends to be conformity between the direction of pseudotransverse divisions and the direction of intrusive growth. This suggests that both phenomena may be controlled by the same mechanism. All this is reminiscent of the situation in the cambium of conifers (B a nn a n 1966; H e jn ow ic z 1968).

What may be the mechanism controlling the direction and conformity of the oriented phenomena in the cambium? The answer to this question is obscure. However several analogous processes showing preference for one direction and reversals of direction during development may be mentioned: for instance, deposition of spirally arranged fibrils in cell walls of some seaweeds (Preston 1964) and rotation of growing sporangiophores in Phycomyces (Roelofsen 1964). The problem of explaining directional preferences and reversals in these phenomena also is not solved.

Unidirectional orientation of pseudotransverse divisions and of overlapping of the cambial initials can be considered as a mechanism leading to the appearance of inclination of wood grain in a predominant direction (N e w m a n 1955; B a n n a n 1966; H e j n o w i c z 1968). The general predominance of S-orientation observed in Aesculus suggests that S-spiral grain should occur in this species. On the contrary, however, Z-spiral grain is a common feature of this species. In fact, we never observed S-spirality once among all the thousands of Aesculus trees which we examined in Lower Silesia. If young stems characteristically had Z-spiral grain and if the direction of partitions were random the angle of the spiral might be expected to increase due to the geometrical effect accompanying the increase of the radius of cambium as was first described by Priestley (Priestley 1945; N e w m a n 1955). Predominance of S-divisions in older stems may thus be considered as a mechanism partially compensating for this increase of Z-spirality. Obviously the problem of spiral grain in Aesculus needs further study. 


\section{SUMMARY}

The terminal layer of xylem (TLX) in each annual ring preserves the cell pattern which existed in the cambium during the formation of that layer. TLX layers from successive annual rings were used to determine the direction of orientation (to the left or to the right) of pseudotransverse divisions ( $p t r)$ and of intrusive growth $(i g)$ of fusiform initials in cambium of a few broadleaved trees. The direction of ig was determined from the direction in which rays were split. A tendency toward one direction was observed in Alnus (ptr), Aesculus (ptr and ig), Liriodendron (ig) and Carpinus (ig). A conformity between the direction of ptr and ig was observed in Aesculus. This suggests that both are controlled by the same mechanism. The data for relatively large surface areas of cambium in Aesculus and Liriodendron indicate a pattern of domains characterized by directional conformity. A change of the pattern with time was observed in Liriodendron.

This investigation has been financed in part by a grant of the United States Department of Agriculture under P. L. 480. The intensive cooperation of Dr. J. A. $\mathrm{R}$ omberger in discussing the problem and preparing the manuscript is gratefully acknowledged.

Departament of Plant Anatomy and Cytology

University of Wroctaw, ul. Kanonia 6, Wroctaw

(Entered: February 28, 1969).

\section{REFERENCES}

B annan M. W., 1950, The frequency of anticlinal divistions in fusiform cambial cells of Chamaecyparis, Amer. J. Bot. 37:511-519.

B a n n a n M. W., 1964, Tracheid size and anticlinal divisions in the cambium of Pseudotsuga, Can. J. Bot. 42:603-631.

B a n n a M. W., 1966, Spiral grain and anticlinal divisions in the cambium of conifers, Can. J. Bot. 44:1515-1538.

B arghiorn E. S. Jr., 1941, The onitogenetic development and phylogenetic specialization of rays in the xylem of dicotyledons II. Modification of the multiseriate and aniseriate rays, Amer. J. Bot. 28:273-282.

$\mathrm{C}$ h e a d le V. I. and K. Es a u, 1964, Secondary phloem of Liriodendron tulipifera, Univ. Calif. Publ. Bot. 50:944-951.

C u m b ie B. G., 1967, Developmental changes in the vascular cambium in Leitneria floridana, Amer. J. Bot. 54: $414-424$.

Evert R. F., Some aspects of cambial development in Pyrus communis, Amer. J. Bot. $481479-488$.

He jnowicz Z., 1961, Anticlinal division, intrusive growth, and loss of fusiform initials in nonstoried cambium, Acta Soc. Bot. Pol. 30: 729-748.

Hejnowicz Z., 1964, Orientation of partition in pseudotransverse division in cambia of some conifers, Can. J. Bot. 42: 1685-1691. 
Hejnowicz Z., 1968, The structural mechanism involved in the changes of grain in timber, Acta Soc. Bot. Pol. 37: 347-365.

J on e s B. E., 1963, Cell adjustments accompanying the development of spiral grain in a specimen of Pseudotsuga taxifolia, Brit. Commonwealth Forestry Rev. 42: $151-158$.

N e w m a n I. V., 1955, Miscelaneous notes on inclination of grain in Pinus radiata D. Don and Pinus sp. Laboratory Report No. 1, Forest Products Laboratory, CSIRO.

Preston R. D., 1964, Structural and mechanical aspects of plant cell walls with particular reference to synthesis and growth. In ,The formation of wood in forest trees", ed. M. H. Zimmermann, Acad. Press.

Priestley J. H., 1945, Observations on spiral grain in timber, Amer. J. Bot. 32: $277-284$.

R o e 1 of s e n P. A., 1949, The origin of spiral growth in phycomyces sporangiophores, Rec. Trev. Bot. Neerl. 57: 73-108.

Smith F. H. 1967, Effects of balsam woolly aphid (Adelges piceae) infestation on cambial activity in Abies grandis, Amer. J. Bot. 54: 1215-1223.

$\mathrm{W}$ a is e $1 \mathrm{Y}$. and A. F a hn, 1965, The effect of enviroment on wood formation and cambial activity in Robinia pseudoacacia L., New Phytol. 64: 436-442.

\section{Ukierunkowane zjawiska morfogenetyczne w kambium drzew liściastych}

\section{Streszczenie}

Stwierdzono, że układ komórek w warstwie drewna tworzonej pod koniec okresu funkcjonowania kambium jako granica przyrostu rocznego, jest taki sam jak w kambium w momendie tworzenia tej warstwy. Fakt ten wykorzystano do odtwarzania historii kambium u drzew liściastych. Badając skrętność ((kierunek nachylenia) antyklinalnych ścian podziałowych we wrzecionowatych komórkach inicjalnych, skrẹtność zachodzenia na siebie rosnących intruzywnie końców wrzecionowatych komórek inicjalnych oraz skrętność rozcinania promieni łykodrzewnych przez intruzywnie rosnące końce stwierdzono, że jest ona jednakowa na mniejszym lub większym obszarze kambium. Skrętność różnych procesów jest taka sama na danym obszarze kambium. 